\title{
PENGARUH MOTIVASI DAN DISIPLIN KERJA TERHADAP KINERJA GURU SD NEGERI 21 PALEMBANG
}

\author{
Pantani Dahlan \\ Dosen Fakultas Ekonomi Universitas Palembang
}

\begin{abstract}
ABSTRAK
Metode yang digunakan dalam penelitian ini adalah perhitungan menggunakan regresi linier berganda adalah menggunakan SPSS. Di mana variabel $\mathrm{X}_{1}$ adalah motivasi dan variabel $\mathrm{X}_{2}$ adalah disiplin kerja yang mempengaruhi variabel $\mathrm{Y}$ adalah Kinerja.

Pada variabel motivasi $\left(\mathrm{X}_{1}\right)$ diperoleh $\mathrm{t}_{\text {hitung }}$ sebesar -1,202 dengan tingkat signifikan sebesar 0,242 karena signifikansinya $0,242 \geq 0,05$ maka H0 ditolak dan HI di terima, berdasarkan uji hipotesis bahwa motivasi tidak berpengaruh terhadap kinerja guru. Sedangkan nilai $t_{\text {hitung variabel disiplin kerja }}\left(\mathrm{X}_{2}\right)$ sebesar 3,323 dengan tingkat signifikan sebesar 0,03 karena signifikan $0,03<0,05$ maka disiplin kerja berpengaruh terhadap kinerja guru secara parsial. Uji F (secara simultan) pada pengujian variabel independen (motivasi, disiplin kerja) secara bersama-sama terhadap variabel dependen (kinerja) diperoleh nilai $\mathrm{F}_{\text {hitung }}$ sebesar 37,520 dengan tingkat signifikan 0,000 karena nilai signifikan jauh lebih kecil dari pada 0,05 maka dapat dinyatakan bahwa variabel independen yang meliputi variabel motivasi, disiplin kerja secara bersama-sama berpengaruh terhadap kinerja.
\end{abstract}

\section{Kata Kunci : motivasi,disiplin kerja terhadap kinerja}

\section{PENDAHULUAN}

\subsection{Latar Belakang}

Manajemen sumber daya manusia sangat penting bagi perusahaan dalam mengelola, mengatur, dan memanfaatkan pegawai sehingga dapat berfungsi secara produktif untuk tercapainya tujuan perusahaan.Sumber daya manusia di perusahaan perlu dikelola secara professional agar terwujud keseimbangan antara kebutuhan pegawai dengan tuntutan dan kemampuan organisasi perusahaan. Mulyadi S (2017). MSDM adalah pemanfaatan sejumlah individu untuk mencapai tujuan-tujuan dalam organisasi.Manajemen Sumber Daya Manusia (MSDM) adalah bagian dari fungsi manajemen. Manajemen sumber daya manusia merupakan bagian dari manajemen yang lebih fokus kepada peranan pengaturan manusia dalam mewujudkan tujuan organisasi atau perusahaan.

Sumber daya manusia merupakan tokoh sentral dalam organisasi maupun perusahaan. Agar aktivitas manajemen berjalan dengan baik, perusahaan harus memiliki karyawan yang berpengetahuan dan berketrampilan tinggi serta usaha untuk mengelola perusahaan seoptimal mungkin sehingga kinerja karyawan meningkat. Kinerja guru mempunyai spesifikasi tertentu.Kinerja guru dapat dilihat dan diukur berdasarkan spesifikasi atau kriteria kompetensi yang harus dimiliki oleh setiap guru.Kinerja yang baik adalah kinerja yang optimal, yaitu kinerja yang sesuai dengan standart organisasi dan mendukung tercapainya tujuan organisasi. Organisasi yang baik adalah meningkatkan kemampuan sumber daya manusianya, karena hail ini merupakan kunci untuk meningkatkan kinerja guru.

Kinerja guru itu baik atau tidak tergantung faktor yang mempengaruhi kinerja guru tersebut. Kinerja merupakan gabungan dari tiga faktor yang terdiri dari (a) Pengetahuan, khususnya yang berhubungan dengan pekerjaan yang menjadi tanggung jawab dalam bekerja, (b) 
Pengalaman, tidak sekedar berarti jumlah waktu atau lamanya bekerja, tetapi berkenaan juga dengan substansi yang dikerjakan, (c) Kepribadian, berupa kondisi di dalam diri seseorang menghadapi bidang kerjanya, seperti minat, bakat, motivasi kerja, dan disiplin kerja.

Salah satu faktor yang mempengaruhi kinerja guru, Motivasi merupakan salah satu upaya untuk meningkatkan prestasi kerja pegawai (Hasibuan, 2015: 141).Motivasi dan prestasi adalah dua elemen yang konstruktif dan korelatif. Keduanya saling mensyaratkan dan tidak bisa dilepaskan dengan yang lain. Prestasi kerja pegawai akan rendah apabila tidak memiliki motivasi untuk melaksanakan pekerjaan itu. Sebaliknya kalau pegawai tersebut memiliki motivasi yang tinggi dalam bekerja, maka dapat menghasilkan kinerja pegawai yang tinggi. Motivasi merupakan hal yang penting karena motivasi akan mendorong dan menggerakkan seseorang untuk melakukan sesuatu lebih bersemangat, terutama dalam hal ini menyangkut motivasi kerja yang berperan dalam prestasi kerja pegawai yang bersangkutan.

Selain motivasi yaitu disiplin kerja. Disiplin kerja guru merupakan salah satu bagian dari kematangan kepribadian seseorang dan merupakan salah satu kunci untuk mencapai tujuan dan dapat tercapainya tujuan organisasi.Disiplin kerja guru terlihat dari penggunaan waktu kerja yang tepat, teladan pemimpin, pengawasan yang dilakukan atasan atau kepala sekolah, penggunaan sarana dan prasarana, ketaatan pada aturan kerja, dan mengikuti prosedur yang telah ditetapkan oleh sekolah. Disiplin kerja akan terlaksana jika atasan atau kepala sekolah mengawasi para guru pada saat mereka melakukan kegiatan. Pengawasan itu dilakukan bertujuan untuk melihat para guru dan tenaga kependidikan yang lain bekerja sesuai dengan prosedur yang ada atau tidak. Ketaatan dalam melaksanakan pekerjaan juga akan mempengaruhi disiplin kerja guru tersebut. Apabila seorang guru mengikuti aturan sekolah berarti ia memiliki rasa tanggung jawab yang tinggi terhadap tugas yang diberikan oleh kepala sekolah.

Berdasarkan hasil studi pendahuluan yang dilakukan dengan pengawas bahwa kinerja guru belum maksimal penyebabnya diduga karena motivasi yang dimiliki guru beragam dan kadang berubah-ubah sesuai dengan kondisi masing-masing individu. Permasalahan yang muncul mengenai kinerja guru diantaranya: (1) perencanaan pembelajaran belum dibuat secara optimal karena RPP dan perangkat pembelajaran masih ada yang copy paste dari Kementrian Pendidikan Nasional; (2) dalam pelaksanaan pembelajaran beberapa guru belum menggunakan berbagai pendekatan;(3) dalam pelaksanaan pembelajaran beberapa guru belum menggunakan berbagai media dan sumber pembelajaran; (4) berdasarkan data laporan bahwa penilaian pembelajaran dan administrasi guru kelas belum tersusun secara lengkap. Permasalahan yang disampaikan oleh beberapa kepala sekolah yang telah diwawancarai bahwa kinerja guru sudah dapat dikatakan baik namun, belum maksimal sehingga kinerja guru perlu ditingkatkan.

Penelitian ini dilakukan kepada seluruh guru SD baik guru mata pelajaran, guru kelas, guru berstatus PNS maupun Non PNS. Karena semua guru memiliki kesempatan yang sama untuk melakukan kinerja yang baik, sehingga dapat mencapai tujuan yang maksimal. Meningkatnya kinerja guru, baik guru mata pelajaran, guru kelas, guru berstatus PNS maupun Non PNS diharapkan dapat meningkatkan kualitas pembelajaran, sehingga dapat menciptakan manusia yang memiliki mutu dan kualitas pendidikan yang tinggi. 
Tabel 1.1

Rekapitulasi Absen Guru

SD Negeri 21 Palembang

2019

\begin{tabular}{|c|c|c|c|c|}
\hline \multirow{2}{*}{ Bulan } & \multicolumn{4}{|c|}{ Tahun 2019 } \\
\cline { 2 - 5 } & A & I & S & T \\
\hline Januari & - & - & - & - \\
\hline Februari & - & 2 & - & 3 \\
\hline Maret & 2 & 1 & - & - \\
\hline April & 2 & - & 1 & 5 \\
\hline Mei & - & - & - & - \\
\hline Juni & 1 & 2 & 2 & - \\
\hline Juli & - & 4 & - & 6 \\
\hline Agustus & - & - & 1 & 5 \\
\hline September & 1 & - & 2 & 3 \\
\hline Oktober & - & - & 1 & 2 \\
\hline November & 2 & 1 & - & 1 \\
\hline Desember & - & - & - & - \\
\hline Jumlah & 8 & 10 & 7 & 25 \\
\hline
\end{tabular}

Sumber: SD Negeri 21 Palembang

Ket: A: alpa, I: izin, S: sakit, T: terlambat

Dari tabel rekapitulasi absensi dari SD Negeri 21 Palembang, bahwa masih banyak guru yang tidak disiplin, masih ada datang kesekolah tidak tepat waktunya. Berdasarkan latar belakang, maka muncul dugaan bahwa kinerja guru Sekolah Dasar Negeri 21 Palembang masih perlu ditingkatkan agar kualitas kerjanya bisa lebih maksimal. Untuk dapat meningkatkan kualitas kinerjanya, guru harus memiliki motivasi yang tinggi dalam melakukan pekerjaannya. Untuk mengetahui secara pasti dugaan tersebut, peneliti tertarik untuk meneliti secara langsung kinerja guru khususnya guru Sekolah Dasar Negeri 21 Palembang Kecamatan Ilir Barat I Kota Palembang. Oleh karena itu, peneliti mengadakan penelitian dengan mengambil judul penelitian
:"Pengaruh Motivasi Disiplin Kerja Terhadap Kinerja Guru Sekolah Dasar Negeri 21 Palembang"

\subsection{Perumusan Masalah}

Berdasarkan latar belakang, maka perumusan masalah dalam penelitian ini adalah sebagai berikut:

1. Apakah motivasi dan disiplin kerja berpengaruh secara parsial terhadap kinerja guru SD Negeri 21 Palembang ?

2. Apakah motivasi dan disiplin kerja berpengaruh secara simultan terhadap kinerja guru SD Negeri 21 Palembang?

\subsection{Tujuan Penelitian}

Berdasarkan latar belakang dan perumusan masalah, maka tujuan dari penelitian yang akan dilakukan adalah sebagai berikut. 
1. Untuk mengetahui pengaruh motivasi terhadap kinerjaguru SD Negeri 21 Palembang.

2. Untuk mengetahui pengaruh disiplin kerja terhadap kinerjaguru SD Negeri 21 Palembang.

3. Untuk mengetahui seberapa besar pengaruh motivasi dan disiplin kerja terhadap kinerja guru SD Negeri 21 Palembang.

\subsection{Manfaat Penelitian}

1. Bagi SD Negeri 21 Palembang.

Diharapkan hasil penelitian ini dijadikan bahan masukan yang mungkin berguna bagi pemecahan masalah yang pengaruh motivasi dan disiplin kerja terhadap kinerja guru.

\section{Bagi Peneliti}

Bagi penulis sebagai bahan melatih menulis \& berpikir ilmiah pada bidang manajemen sumber daya manusia khususnya yang berkaitan dengan pengaruhmotivasi dan disiplin kerja terhadap kinerja guru.

\section{Bagi Peneliti Lainnya}

Sebagai acuan dan perbandingan dalam penelitian mengenai objek masalah yang sama dimasa yang akan datang.

\section{TINJAUAN PUSTAKA}

\subsection{Landasan Teori}

\subsubsection{Pengertian Motivasi Kerja} Selanjutnya Anwar Prabu Mangkunegara

menyatakan: Motif merupakan suatu dorongan kebutuhan dalam diri pegawai yang perlu dipenuhi agar pegawai tersebut dapat menyesuaikan diri terhadap lingkungannya, sedangkan motivasi adalah kondisi yang menggerakkan pegawai agar mampu mencapai tujuan dari motifnya.

Berdasarkan uraian diatas dapat disimpulkan bahwa motivasi adalah dorongan atau penggerak seseorang untuk mau bertindak dan bekerja dengan giat sesuai dengan tugas dan kewajibannya untuk mencapai tujuan yang telah ditentukan.

\subsubsection{Tujuan Motivasi}

Seseorang memerlukan motivasi agar orang tersebut mau melakukan suatu pekerjaan. Hasibuan (2015: 146) menyatakan tujuan motivasi antara lain sebagai berikut :

1. Meningkatkan moral dan kepuasan kerja karyawan.

2. Meningkatkan produktivitas kerja karyawan.

3. Mempertahankan kestabilan karyawan perusahaan.

4. Peningkatan kedisiplinan karyawan.

5. Mengefektifkan pengadaan karyawan.

6. Mencitakan suasana dan hubungan kerja yang baik.

7. Meningkatkan loyalitas, kreativitas, dan partisipasi karyawan.

8. Meningktakan tingkat kesejahteraan karyawan.

9. Mempertinggi rasa tanggung jawab karyawan terhadap tugas-tugasnya.

10. Meningkatkan efisiensi penggunaan alat-alat dan bahan baku.

Berdasarkan pendapat 
pendapat yang telah disampaikan, dapat disimpulkan bahwa perusahaan harus dapat memotivasi kerja karyawan agar karyawan bekerja dengan penuh semangat untuk mencapai tujuan. Begitu juga di sekolah, jika sekolah dapat memotivasi guru sehingga guru bekerja dengan senang dan penuh semangat, maka diharapkan hasil kerja guru akan optimal.

\subsubsection{Faktor - faktor yang} Mempengaruhi Motivasi

Faktor-faktor mempengaruhi motivasi adalah :

1. Faktor Ekstern

- Lingkungan kerja

- Pemimpin dan kepemimpinannya

- Tuntunan perkembangan organisasi atau tugas

- Dorongan atau bimbingan atasan.

2. Faktor Intern

- Pembawaan Individu

- Tingkat pendidikan

- Pengalaman masa lampau

- Keinginan atau harapan masa depan.

\subsubsection{Teori Motivasi}

Ada beberapa teori motivasi menurut para ahli yaitu sebagai berikut :

\section{Teori Abraham Maslow}

Penjelasan mengenai konsep motivasi manusia menurut Abraham Maslow mengacu pada lima kebutuhan pokok yaitu :

a. Kebutuhan yang bersifat fisiologi, kebutuhan ini terlihat dalam tiga hal pokok yaitu : sandang, pangan dan papan.

b. Kebutuhan keamanan, kebutuhan ini mengarah kepada rasa keamanan, ketentraman dan jaminan seseorang dalam kedudukannya, jabatannya, wewenangnya dan tanggung jawabnya sebagai karyawan.

c. Kebutuhan sosial, kebutuhan akan kasih sayang dan bersahabatan dalam kelompok kerja atau antar kelompok.

d. Kebutuhan harga diri, kebutuhan akan kedudukan dan kehormatan yang diterima dalam suatu lingkungan.

e. Kebutuhan aktualisasi diri, hal ini merupakan kebutuhan untuk mewujudkan segala kemampuan dan seringkali nampak pada hal-hal yang sesuai untuk mencapai citra dan cita diri seseorang senantiasa percaya pada diri sendiri.

\section{Teori McClelland}

Menurut McClelland, ada tiga hal yang melatar belakangi motivasi seseorang, yaitu :

a. Kebutuhan akan prestasi, kebutuhan seseorang untuk memiliki pencapaian signifikan, menguasai beberapa keahlian atau memiliki standar yang tinggi. Hal itu tercapai dengan cara merumuskan tujuan, timbal balik, tanggung jawab pribadi dan bekerja keras.

b. Kebutuhan akan kekuasaan, 
kebutuhan ini disadari oleh keinginan seseorang untuk mengatur atau memimpin orang lain. Hal ini sangat tergantung pada pengalaman masa kecil, kepribadian, pengalaman kerja dan tipe organisasi.

c. Kebutuhan akan afiliasi, kebutuhan ini adalah yang disadari oleh keinginan untuk mendapatkan atau menjalankan hubungan yang baik dengan orang lain. Orang merasa ingin disukai dan diterima oleh sesamanya. Hal itu tercapai dengan cara bekerja sama dan sosialisasi.

\subsubsection{Pengertian Disiplin}

MalayuS.P.Hasibuan(2015:19 3) menyatakan "kedisiplinan adalah kesadaran dan kesediaan seseorang menaati semua peraturan perusahaan dan norma-norma sosial yang berlaku". Disiplin juga sangat penting artinya bagi guru.

Berdasarkan

beberapa pendapat yang telah disampaikan, dapat disimpulkan bahwa disiplin kerja adalah ketaatan yang dilakukan seseorang secara teratur dan terus-menerus terhadap peraturan yang telah ditetapkan oleh lembaga tempat dia bekerja. Begitu juga disekolah, seorang guru dituntut untuk selalu taat terhadap tata tertib yang berlaku karena dapat mendukung kelancaran pelaksanaan tugas yang diberikan kepadanya.

\subsubsection{TujuanDisiplin}

MenurutMalayuS.P.Hasibua n (2015) tujuan disiplin yaitu :

1. Agar para karyawan menepati segala peraturan dan kebijaksanaan ketenaga kerjaan maupun peraturan dan kebijaksanaan perusahaan yang berlaku, serta melaksanakan perintah atasan atau manajemen.

2. Agar karyawan dapat melaksanakan pekerjaan dengan sebaik-baiknya serta memberikan pelayanan yang maksimum kepada pihak tertentu yang berkepentingan dalam perusahaan.

3. Agar karyawan dapat menggunakan dan memelihara sarana dan prasarana, barang dan jasa pada perusahaan.

4. Agar karyawan mampu menghasilkan produktivitas yang tinggi sesuai dengan harapan perusahaan, baik dalam jangka pendek maupun jangka panjang.

\subsubsection{Pentingnya Kedisiplinan}

Kerja

Menurut Hasibuan (2015: 193-194) : "Disiplin yang baik mencerminkan besarnya rasa tanggung jawab seseorang terhadap tugas-tugas yang diberikan kepadanya". Hal ini mendorong gairah kerja, semangat kerja, dan terwujudnya tujuan perusahaan, karyawan, dan masyarakat. Oleh karena itu, setiap manajer selalu berusaha agar para bawahannya mempunyai disiplin yang baik. Seorang manajer dikatakan efektif dalam kepemimpinannya, jika para bawahannya berdisiplin baik.

Peraturan sangat diperlukan untuk memberikan bimbingan dan penyuluhan bagi karyawan dalam 
menciptakan tata tertib yang baik di perusahaan. Dengan tata tertib yang baik, semangat kerja, moral kerja, efisiensi, dan efektifitas kerja karyawan akan meningkat.Hal ini akan mendukung tercapainya tujuan perusahaan, karyawan, dan masyarakat. Jelasnya perusahaan sulit mencapai tujuannya, jika karyawan tidak mematuhi peraturan-peraturan perusahaan tersebut. Kedisiplinan perusahaan dikatakan baik, jika sebagian besar karyawan menaati peraturanperaturan yang ada. Hukuman diperlukan dalam meningkatkan kedisiplinan dan mendidik karyawan supaya menaati semua peraturan perusahaan. Pemberian hukuman harus adil dan tegas terhadap semua karyawan. Dengan keadilan dan ketegasan, sasaran pemberian hukuman akan tercapai. Peraturan tanpa disertai pemberian hukuman yang tegas bagi pelanggannya bukan menjadi alat pendidik bagi karyawan.

\subsubsection{Pengertian Kinerja}

Kata kinerja merupakan terjemahan dari Bahasa Inggris,yaitu dari kata performace. Banyak pakar atau peneliti memberi pengertian yang berbeda mengenai kinerja guru. Barnawi dan Mohammad Arifin(2016:14) menyatakan : Kinerja guru dapat diartikan sebagai tingkat keberhasilan guru dalam melaksanakan tugas pendidikan sesuai dengan tanggung jawab dan wewenangnya berdasarkan standar kinerja yang telah ditetapkan selama periode tertentu dalam kerangka mencapai tujuan pendidikan.

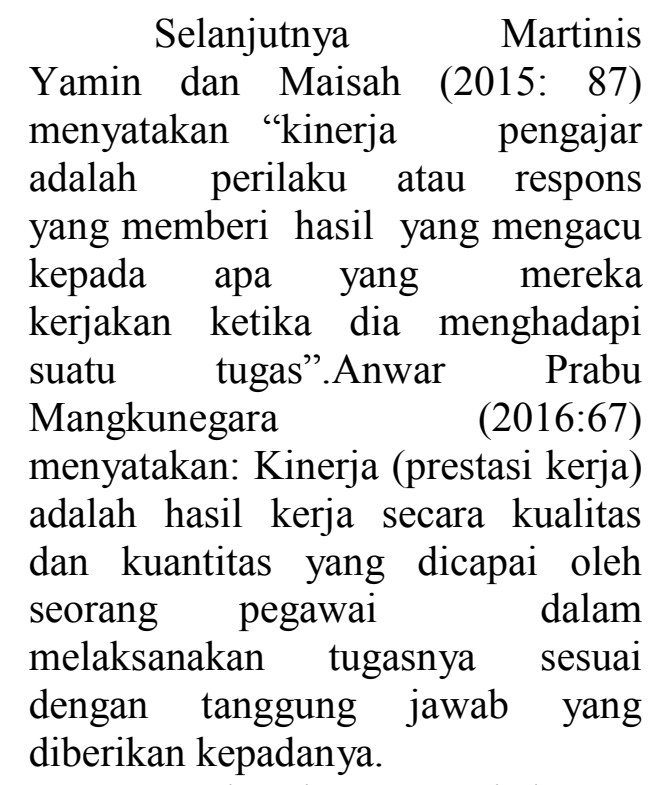

Berdasarkan

beberapa

pendapat yang telah disampaikan, dapat disimpulkan bahwa pengertian kinerja guru adalah tingkat keberhasilan kerja yang dicapai oleh seorang guru dengan kecakapan dan keahlian yang dimiliki dalam melaksanakan tugas sesuai dengan tugas kerjanya. Guru sangat berperan dalam proses belajar mengajar. Keberhasilan sekolah tidak dapat terlepas dari peran guru sebagai tenaga pendidik dalam menghasilkan lulusan yang mampu menghadapi persaingan hidup yang semakin ketat.

\subsubsection{Faktor-faktor yang Mempengaruhi Kinerja}

Menurut Roobert L. Mathis

dan Jhon H, Jackson (2015: 82)

Faktor-faktor yang mempengaruhi kinerja yaitu :

1. Kemampuan mereka,

2. Motivasi,

3. Dukungan yang diterima,

4. Keberadaan pekerjaan yang mereka lakukan, dan

5. Hubungan mereka dengan organisasi. 
Berdasarkan pengertian diatas, penulis menarik kesimpulan bahwa kinerja merupakan kualitas dan kuantitas dari suatu hasil kerja (output) individu maupun kelompok dalam suatu aktivitas tertentu yang diakibatkan oleh kemampuan alami atau kemampuan yang diperoleh dari proses belajar serta keinginan untuk berprestasi.

\subsubsection{Indikator Kinerja Guru}

Indikator kinerja merupakan aspek-aspek yang menjadi ukuran tolak ukur dalam menilai kinerja. 4 dimens iyang dapat dijadikan sebagai tolak ukur dalam menilai kinerja secara umum, yaitu;

1. Kualitas, yaitu ; tingkat kesalahan, kerusakan, kecermatan.

2. Kuantitas, yaitu jumlah pekerjaan yang dihasilkan.

3. Penggunaan waktu dalam kerja, yaitu tingkat ketidak hadiran, keterlambatan, waktu kerja efektif/jam kerja hilang.

4. Kerjasama dengan orang lain dalam bekerja.
Dari empat indikator kinerja diatas dapat disimpulkan bahwa ada dua hal terkait dengan aspek keluaran atau hasil pekerjaan yaitu kualitas hasil, kuantitas keluaran dan dua hal terkait aspek perilaku individu yaitu penggunaan dalam bekerja (tingkat kepatuhan terhadap jam kerja, disiplin) dan kerja sama sehingga keempat indikator diatas mengukur kinerja padalevel individu.

\subsection{Kerangka Pemikiran}

Konsep Kerangka pemikiran adalah istilah dan defenisi yang digunakan untuk menggambarkan secara abstrak mengenai kejadian, keadaan, kelompok atau individu yang menjadi perhatian ilmu sosial. Konsep adalah abstraksi mengenai suatu fenomena yang dirumuskan atas dasar generalisasi.

Untuk mendapatkan batasanbatasan yang lebih jelas mengenai variabel-variabel yang akan diteliti, maka defenisi konsep yang digunakan dalam pengertian ini adalah :

\section{Gambar 2.1}

Kerangka Pemikiran

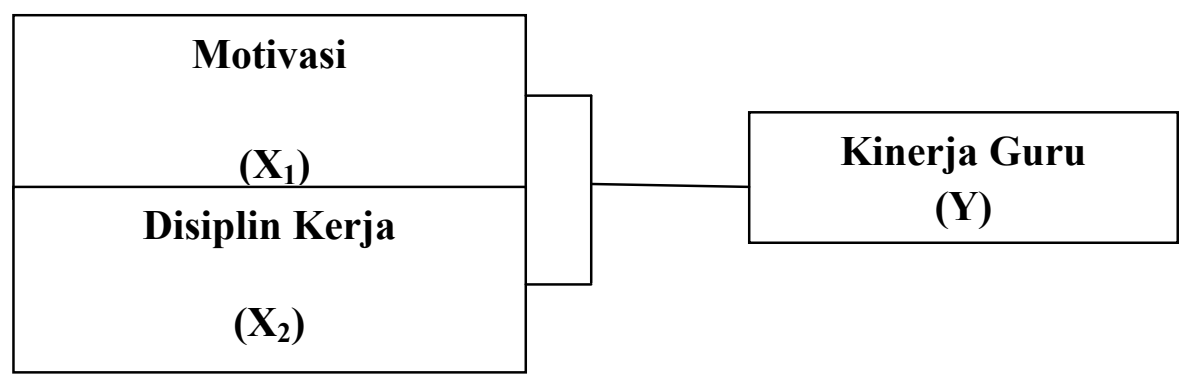

\subsection{Hipotesis}

Berdasarkan perumusan masalah yang telah ditetapkan maka dirumuskan hipotesis sebagai berikut, ada pengaruh signifikan antara motivasi dan disiplin kerja terhadap kinerja guru SD Negeri 21 Palembang. Hipotesis adalah dugaan sementara yang kebenarannya masih 
harus dilakukan pengujian. Disini kesimpulan sementara adalah :

- Ho : Tidak ada pengaruh motivasi terhadap kinerja guru SD Negeri 21 Palembang.

H1 : Ada Pengaruh motivasi terhadap kinerja guru SD Negeri 21 Palembang.

- Ho : Tidak ada pengaruh disiplin kerja terhadap kinerja guru SD Negeri 21 Palembang.

H1 : Ada pengaruh disiplin kerja terhadap kinerja guru SD Negeri 21 Palembang.

- Ho : Tidak ada pengaruh motivasi dan disiplin kerja terhadap kinerja guru SD Negeri 21 Palembang.

H1 : Ada pengaruh motivasi dan disiplin kerja terhadap kinerja guru SD Negeri 21 Palembang.

\section{METODE PENELITIAN}

\subsection{Objek Penelitian}

Penelitian ini dilakukan di SD Negeri 21 Palembang. Yang berlokasi di Jalan Puncak Sekuning No. 84, 26 Ilir Palembang. Pemilihan objek penelitian ini dengan cara disengaja dengan pertimbangan bahwa SD Negeri 21 Palembang akan membantu untuk memberikan data dan informasi yang sangat berguna dalam menyelesaikan penulisan karya ilmiah ini.

\subsection{Ruang Lingkup Penelitian}

Agar penelitian ini terarah dan tidak menyimpang dari permasalahan, maka penulis membatasi pada permasalahan yaitu pengaruh motivasi dan disiplin kerja terhadap kinerja guru SD Negeri 21 Palembang.

\subsection{Desain Penelitian}

Penelitian ini berjenis penelitian Analisi Kuantitatif yang membahas ada tidaknya pengaruh antara variabel bebas dan variabel terikat, dalam hal ini variabel bebas $\left(\mathrm{X}_{1}\right)$ adalah Motivasi, $\left(\mathrm{X}_{2}\right)$ adalah Disiplin Kerja, dan variabel terikat (Y) adalah Kinerja.

\subsection{Jenis dan Sumber Data}

Adapun jenis data yang digunakan dalam penelitian ini adalah :

a. Data Primer adalah data yang diperlukan dalam penelitian ini, diperoleh dan dikumpulkan secara langsung dari jawaban responden guru SD Negeri 21 Palembang dengan angket mengenai disiplin kerja, motivasi kerja dan kinerja guru.

b. Data Sekunder adalah mengumpulkan data melalui dokumen relevan dengan kajian penelitian ini yang bersumber dari website. Data dokumentasi berupa gambaran umum organisasi, jumlah pegawai, dan datadata dokumentasi lainnya yang relevan.

Teknik pengumpulan data pada penelitian ini adalah :

1. Teknik Angket (kuesioner)

Teknik angket adalah suatu cara pengumpulan data dengan menyebarkan 
pertanyaan kepada responden dan responden akan memberikan respon atas pertanyaan tersebut (Husein Umar. 2015:82). Pemilihan teknik angket dalam penelitian ini agarmemperoleh data yang akuratsecara langsung dari orang-orang yang akan dimintai data.

2. Dokumentasi

Teknik dokumentasi adalah pengumpulan data dan informasi melalui arsip dan dokumentasi (Husein Umar. 2015:83). memperoleh pendukung dibutuhkan dari sumber yang dapat dipercaya, maka digunakan teknik dokumentasi. Teknik dokumentasi berguna untuk memperoleh data tentang jumlah karyawan dan data tentang gambaran umum pada Dengan cara ini peneliti dapat menetukan dan menyusun variabel yang sesuai.

\subsection{Populasi dan Sampel}

Populasi adalah wilayah generalisasi yang terdiri atas objek / subjek yang mempunyai kualitas dan karakteristik tertentu yang ditetapkan oleh peneliti untuk dipelajari dan kemudian ditarik kesimpulannya (Sugiyono, 2015). Dalam penelitian ini populasi adalah seluruhguruPNS dan Non PNSSDNegeri

21Palembang,berjumlah 25 orang. SampeladalahSampel adalah bagian atau contoh kecil yang mewakili sifat dan karakter. Penelitian ini menggunakan teknik sampling jenuh, yaitu teknik penentuan sampel bila semua anggota populasi di gunakan sebagai sampel. Hal ini dilakukan karena jumlah populasi relatif kecil, yaitu berjumlah 25 orang.

Pada penelitian ini, maka yang menjadi objek penelitian adalah seluruh populasi pegawai dan guru SD Negeri 21 Palembang yang berjumlah 25 orang.

Tabel 3.1

Populasi Guru dan Pegawai SD Negeri 21 Palembang

\begin{tabular}{|c|c|c|}
\hline No & Jabatan/Tugas & $\begin{array}{c}\text { Jumlah } \\
\text { (orang) }\end{array}$ \\
\hline 1 & Kepala Sekolah & 1 \\
\hline 2 & $\begin{array}{c}\text { Wakil Kepala } \\
\text { Sekolah }\end{array}$ & 1 \\
\hline 3 & $\begin{array}{c}\text { Pengajar/ Guru } \\
\text { PNS }\end{array}$ & 17 \\
\hline 4 & $\begin{array}{c}\text { Pengajar/Guru } \\
\text { Non-PNS }\end{array}$ & 6 \\
\hline & Jumlah & $\mathbf{2 5}$ \\
\hline
\end{tabular}

\subsection{Definisi Operasional dan Pengukuran Variabel}

Definisi operasional adalah suatu definisi yang diberikan kepada suatu variabel atau konstrak dengan cara memberikan arti, atau menspesifikasikan kegiatan ataupun memberikan suatu operasional yang diperlukan untuk mengukur konstrak atau variabel tersebut. Dalam penelitian ini definisi operasional variabel adalah sebagai berikut:

\section{Variabel bebas ( $\mathrm{X}_{1}$ Motivasi)}

Motivasi merupakan dorongan atau daya penggerak yang timbul dari diri, tanpa ada paksaan dari siapapun untuk melakukan suatu pekerjaan. 
2. Variabel Bebas $\left(X_{2}\right.$ Disiplin Kerja)

Disiplin kerja adalah sikap ketaatan dan kesediaan karyawan terhadap peraturan tertulis maupun tidak tertulis yang tercermin dalam bentuk tingkah laku dan perbuatan untuk mencapai suatu tujuan.

3. Variabel Tidak Bebas (Y Kinerja Guru)

Kinerja guru adalah hasil kerja yang dapat dicapai oleh pengajar dalam rangka melaksanakan tugas dan tanggung jawabnya.

\subsection{Skala Pengukuran Variabel} Pengukuran variabel dilakukan dengan menggunakan daftar pertanyaan dengan menyebarkan kuesioner kepada responden. Motivasi, Disiplin, dan Kinerja diwujudkan masing-masing dalam 5 pertanyaan.

Skala pengukuran variabel yang digunakan penelitian ini adalah dengan menggunakan Skala Likert, Skala Likert digunakan untuk mengukur sikap, pendapat dan persepsi seseorang atau kelompok tentang fenomena sosial (Sugiyono, $2016: 86$ ).

Dalam melakukan penelitian terhadap variabel-variabel yang akan diuji, pada setiap jawaban akan diberi skor. Skor yang diberikan adalah sebagai berikut:

Tabel 3.3

Instrumen Skala Likert

\begin{tabular}{|c|c|c|}
\hline No & Pernyataan & Skor \\
\hline 1 & Sangat Setuju (SS) & 5 \\
\hline 2 & Setuju (S) & 4 \\
\hline 3 & Kurang Setuju (KS) & 3 \\
\hline 4 & Tidak Setuju (TS) & 1 \\
\hline 5 & Sangat Tidak Setuju (STS) & 2 \\
\hline
\end{tabular}

\subsection{Teknis Analisis}

\subsubsection{Uji Validitas}

Menunjukkan sejauh mana suatu alat pengukur itu mengukur apa yang ingin diukur. Suatu skala pengukur dikatakan valid apabila skala tersebut digunakan untuk mengukur apa yang seharusnya diukur. Peneliti terlebih dahulu melakukan uji validasi dengan menyebarkan kuesioner kepada responden lain dengan menggunakan program SPSS 23.

1. Jika $r_{\text {hitung }}>r_{\text {tabel }}$, maka pertanyaan dinyatakan valid

2. Jika $r_{\text {hitung }}<r_{\text {tabel, }}$ maka pertanyaan dinyatakan tidak valid

Dalam penelitian ini disebarkan kuisioner sebagai alat pengumpulan data yang menyangkut pengaruh motivasi dan disiplin kerja terhadap kinerja guru.

\subsubsection{Uji Reliabilitas}

Pengujian reliabilitas data dilakukan untuk mengetahui sejauh mana suatu pengukur dapat menunjukkan akurasi dan konsistensi butir pertanyaan. Untuk menguji reliabilitas data dignakan Cronbanch Alpha. Menurut 
Sugiyono (2016 : 268) bahwa "Cronbach Alpha merupakan salah satu koefisien reliabilitas yang paling sering digunakan". Skala pengukuran yang reliabel sebaiknya memiliki nilai Cronbach Alpha minimal 0,60.

\subsubsection{Analisi Deskriptif}

Metode penganalisisan data dengan cara menyusun data, mengelompokannya selanjutnya menginter prestasikannya sehingga diperoleh gambaran sebenarnya mengenai kondisi yang akan diteliti.

\subsection{Analisis Deskriptif Statistik}

\subsubsection{Regresi LinearBerganda}

Teknik analisis yang digunakan dalam penelitian ini adalah Analisis regresilinear berganda digunakan untuk mengetahui pengaruh antara variabel bebas dengan variabel terikat, yaitu Disiplin kerja $\left(\mathrm{X}_{1}\right)$ dan Motivasi $\left(\mathrm{X}_{2}\right)$ Terhadap Kinerja Guru (Y) pada SD Negeri 21 Palembang. Adapun rumus regresi linear berganda adalah sebagai berikut (sugiyono,2016: 258)

$$
\mathbf{Y}=\mathbf{a}+\mathbf{b}_{1} \mathbf{X}_{1}+\mathbf{b}_{2} \mathbf{X}_{2}+\mathbf{e}
$$

Keterangan :

$$
\begin{array}{ll}
\mathrm{Y} & =\text { KinerjaGuru } \\
\mathrm{A} & =\text { Koefisien regresi (konstanta) } \\
\mathrm{b}_{1} & =\text { Koefisienregresi } \\
\mathrm{b}_{2} & =\text { Koefisienregresi } \\
\mathrm{X}_{1} & =\text { Motivasi } \\
\mathrm{X}_{2} & =\text { Disiplin } \\
\mathrm{e} & =\text { Faktor kesalahan }(\text { asumsi }=0)
\end{array}
$$

Untuk mengetahui apakah variabel independen berpengaruh atau tidak terhadap variabel dependen maka dapat dilihat dari taraf signifikansinya dengan standar signifikasi 5\%. Apabila tingkat signifikan yang diperoleh dari hasil lebih dari 5\% maka hipotesis ditolak, sebaliknya jika hasil uji hipotesis berada diantara $0-5 \%$ maka hipotesis diterima. Sementara itu, untuk melihat regresi yang dihasilkan berpengaruh positif tau negatif melalui koefesien beta $(\beta)$.

Apabila koefisien beta memiliki tanda minus (-) berarti pengaruh yang dihasilkan adalah negatif, sebaliknya apabila koefisien beta tidak memiliki tanda minus (-), maka arah pengaruh yang dihasilkan adalah positif $(+)$. Dalam penelitian ini analisis regresi ganda digunakan oleh peneliti, karena peneliti bermaksud meramalkan bagaimana keadaan (naik turunnya) variabel dependen (kriterium). Jadi analisis regresi linier ganda akan dilakukan bila jumlah variabel independennya minimal 2

\section{HASIL PENELITIAN DAN PEMBAHASAN}

\subsection{Pembahasan}

Persamaan regresi yang menggambarkan dan menjelaskan pengaruh dua variabel bebas terhadap variabel terikat, dimana hubungan ke tiganya dapat 
digambarkan sebagai suatu garis lurus, untuk melihat variabel karakteristik terhadap kinerja guru maka peneliti menggunakan model regresi berganda sebagai berikut :

$$
\begin{array}{cl|}
\cline { 2 - 3 } & \multicolumn{1}{c|}{\mathbf{Y = a}+\mathbf{b}_{\mathbf{1}} \mathbf{X}_{\mathbf{1}}+\mathbf{b}_{\mathbf{2}} \mathbf{X}_{\mathbf{2}}+\mathbf{e}} \\
\text { Keterangan : } & =\text { KinerjaGuru } \\
\mathrm{Y} & =\text { Koefisien regresi (konstanta) } \\
\mathrm{A} & =\text { Koefisienregresi } \\
\mathrm{b}_{1} & =\text { Koefisienregresi } \\
\mathrm{b}_{2} & =\text { Motivasi } \\
\mathrm{X}_{1} & =\text { Disiplin } \\
\mathrm{X}_{2} & =\text { Faktor kesalahan (asumsi }=0) \\
\mathrm{e} &
\end{array}
$$

\begin{abstract}
Perhitungan ini menggunakan regresi berganda dengan menggunakan SPSS. Dimana variabel $\mathrm{X}_{1}$ adalah disiplin dan variabel $X_{2}$ adalah motivasi yang mempengaruhi variabel $\mathrm{Y}$ adalah kinerja.
\end{abstract}

\subsection{Uji Instrumen}

\subsubsection{Uji Validitas}

Uji validitas adalah sebuah pengukuran terhadap data yang diolah dimana menunjukkan sejauh mana alat pengukur apa yang ingin di ukur. untuk mengukur data penelitian, penulis menggunakan kuesioner yang disebarkan kepada 25 responden seluruh guru dan pegawai SD Negeri 21 Palembang. Pengujian ini dilakukan untuk mengetahui valid atau sahih tidaknya suatu instrumen penelitian.

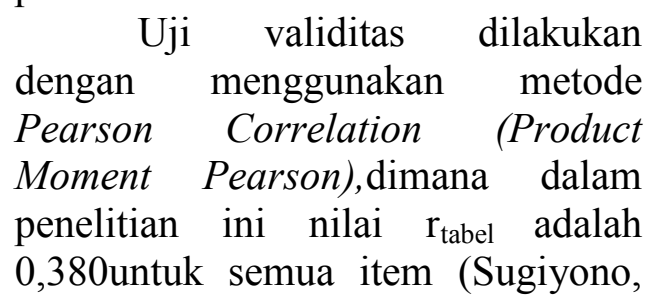

2015). Apabila hasil $r_{\text {hitung }}$ lebih besar dari $r_{\text {tabel, }}$ maka data tersebut valid dan metode kuesioner dapat digunakan untuk penelitian. Pengujian ini dilakukan terhadap variabel bebas $\left(\mathrm{X}_{1}\right), \quad\left(\mathrm{X}_{2}\right)$ dan variabel terikat $(\mathrm{Y})$. Berikut hasil uji validitas selengkapnya dari masingmasing item pertanyaan pada tabel :

\section{a. Validasi Variabel Motivasi}

Dari hasil pengujian validitas dengan menggunakan SPSS 23 (hasil perhitungan dapat dilihat dalam lampiran) diperoleh koefisien validitas setiap item dengan kuesioner berjumlah (6 butir), Syarat suatu instrument dinyatakan valid adalah bila koefisien kolerasi $\geq 0,380$ atau bisa juga membandingkan dengan $r$ tabel. Jika $r$ hitung $>r$ tabel maka instrument tersebut valid (Sugiyono, 2015).Berdasarkan analisis yang telah dilakukan, adapun hasil uji validitas selengkapnya dapat dilihat pada tabel dibawah. 
Tabel 4.21.

Hasil Uji Validitas Motivasi $\left(\mathbf{X}_{1}\right)$

\begin{tabular}{|c|c|c|c|c|}
\hline No Item & R Hitung & RTabel & Kriteria & Keterangan \\
\hline 1 & $0.881^{* *}$ & 0,380 & $\mathrm{r}$ hitung $\geq \mathrm{r}$ table & Valid \\
\hline 2 & $0.935^{* *}$ & 0,380 & $\mathrm{r}$ hitung $\geq \mathrm{r}$ table & Valid \\
\hline 3 & $0.782^{* *}$ & 0,380 & $\mathrm{r}$ hitung $\geq \mathrm{r}$ table & Valid \\
\hline 4 & $0.877^{* *}$ & 0,380 & $\mathrm{r}$ hitung $\geq \mathrm{r}$ table & Valid \\
\hline 5 & $0.727^{* *}$ & 0,380 & $\mathrm{r}$ hitung $\geq \mathrm{r}$ table & Valid \\
\hline 6 & $0.825^{* *}$ & 0,380 & $\mathrm{r}$ hitung $\geq \mathrm{r}$ table & Valid \\
\hline
\end{tabular}

Sumber : Hasil Pengolahan Data Menggunakan SPSS. 23.00

b. Validitas Variabel Disiplin Kerja

Untuk variabel disiplin kerja $\left(\mathrm{X}_{2}\right)$, hasil dari uji validitas yang telah dilakukan bahwa seluruh item ( 5 butir) pertanyaan dalam pertanyaan kuesioner yang digunakan sebagai alat ukur variabel disiplin kerja $\left(\mathrm{X}_{2}\right)$ ternyata semua item pertanyaan dinyatakan valid. Secara terperinci nilai dari masingmasing item dapat dilihat dalam tabel berikut

Tabel 4.22.

Hasil Uji Validitas Disiplin Kerja $\left(\mathbf{X}_{2}\right)$

\begin{tabular}{|c|c|c|c|c|}
\hline No Item & R Hitung & $\begin{array}{c}\mathbf{R} \\
\text { Tabel }\end{array}$ & Kriteria & Keterangan \\
\hline 1 & $0.835^{* *}$ & 0,380 & r hitung $\geq$ r table & Valid \\
\hline 2 & $0.958^{* *}$ & 0,380 & r hitung $\geq$ r table & Valid \\
\hline 3 & $0.845^{* *}$ & 0,380 & r hitung $\geq$ r table & Valid \\
\hline 4 & $0.912^{* *}$ & 0,380 & r hitung $\geq$ r table & Valid \\
\hline 5 & $0.916^{* *}$ & 0,380 & r hitung $\geq$ r table & Valid \\
\hline
\end{tabular}

Sumber : Hasil Pengolahan Data Menggunakan SPSS. 23.00

\section{c. Uji Validitas Kinerja}

Untuk variabel kinerja (Y), hasil dari uji validitas yang telah dilakukan menunjukkan bahwa seluruh item ( 5 butir) pertanyaan dalam kuesioner digunakan sebagai alat ukur variabel kinerja (Y) ternyata semua item pertanyaan dinyatakan valid. Secara terperinci bila dari masing-masing item dapat dilihat dalam tabel berikut :

Tabel 4.23.

Hasil Uji Validitas Kinerja (Y)

\begin{tabular}{|c|c|c|c|c|}
\hline No Item & R Hitung & R Tabel & Kriteria & Keterangan \\
\hline 1 & $0.917^{* *}$ & 0,380 & r hitung $\geq \mathrm{r}$ table & Valid \\
\hline
\end{tabular}




\begin{tabular}{|c|c|c|c|c|}
\hline 2 & $0.880^{* *}$ & 0,380 & $\mathrm{r}$ hitung $\geq \mathrm{r}$ table & Valid \\
\hline 3 & $0.864^{* *}$ & 0,380 & $\mathrm{r}$ hitung $\geq \mathrm{r}$ table & Valid \\
\hline 4 & $0.785^{* *}$ & 0,380 & $\mathrm{r}$ hitung $\geq \mathrm{r}$ table & Valid \\
\hline 5 & $0.674 * *$ & 0,300 & $\mathrm{r}$ hitung $\geq \mathrm{r}$ table & Valid \\
\hline
\end{tabular}

Sumber : Hasil Pengolahan Data Menggunakan SPSS. 23.00

\subsubsection{Uji Reliabilitas}

Uji reliabilitas merupakan alat ukur yang digunakan untuk memastikan instrument penelitian merupakan alat ukur yang akurat dan dapat dipercaya. uji reliabilitas menunjukkan sejauh mana suatuhasil pengukuran relatif konsisten. Apabila pengukuran terhadap aspek yang sama pada alat ukur yang sama atau disebut Internal Consistenly Reliability. Uji ini dapat menunjukkan sejauh mana suatu alat ukur dapat dipercaya atau handal. Pengujian kehandalan variabel atau item menggunakan uji Cronbach Alpha. Apabila nilai $\alpha>\mathrm{r}_{\text {tabel }}$, berarti variabel dan item yang diukur bersifat handal.

Berikut ini tabel hasil uji reliabilitas dari variabel Motivasi dan Disiplin Kerja yang mempengaruhi Kinerja Guru.

Tabel 4.24.

Hasil Uji Reliabilitas

\begin{tabular}{|c|c|c|}
\hline Variabel & Alpha Cronbach $(\boldsymbol{\alpha})$ & Status \\
\hline Motivasi & 0,917 & Reliabel \\
\hline Disiplin Kerja & 0,937 & Reliabel \\
\hline Kinerja & 0,877 & Reliabel \\
\hline
\end{tabular}

\subsection{Analisis Deskriptif Statistik}

\subsubsection{Koefisien Determinasi $\left(R^{2}\right)$}

Digunakan untuk melihat seberapa besar pengaruh variabel bebas terhadap variabel terikat. Dengan kata lain, koefisien determinasi digunakan untuk mengukur besarnya pengaruh variabel bebas yang diteliti yaitu motivasi $\left(\mathrm{X}_{1}\right)$ dan $\left(\mathrm{X}_{2}\right)$ disiplin kerja terhadap prestasi kerja. Dalam output SPSS, koefisien determinan terletak pada tabel model summary dan tertulis R Square. Besarnya R Square berkisar antara angka 0 (nol) sampai dengan 1 (satu). Apabila R Square semakin kecil atau mendekati angka 0 (nol), maka hubungan antara variabel bebas $(\mathrm{X})$ dengan variabel terikat (Y) semakin lemah. Sebaliknya, apabila R Square semakin besar atau mendekati angka 1 (satu), maka hubungan kedua variabel semakin kuat.

Tabel 4.25.

Hasil Uji Determinasi $\left(\mathbf{R}^{2}\right)$

Model Summary

\begin{tabular}{|l|c|r|r|r|}
\hline Model & R & R Square & $\begin{array}{c}\text { Adjusted R } \\
\text { Square }\end{array}$ & $\begin{array}{c}\text { Std. Error of } \\
\text { the Estimate }\end{array}$ \\
\hline 1 & $.879^{\mathrm{a}}$ & .773 & .753 & 1.346 \\
\hline
\end{tabular}


Model Summary

\begin{tabular}{|l|c|r|r|r|}
\hline Model & R & R Square & $\begin{array}{c}\text { Adjusted R } \\
\text { Square }\end{array}$ & $\begin{array}{c}\text { Std. Error of } \\
\text { the Estimate }\end{array}$ \\
\hline 1 & $.879^{\mathrm{a}}$ & .773 & .753 & 1.346 \\
\hline
\end{tabular}

a. Predictors: (Constant), DiSIPLIN,MOTIVASI

a. R dalam analisis regresi berganda menunjukan korelasi (korelation pearson), yaitu korelasi antara dua variabel independent. Angka R di dapat 0,884 artinya korelasi variabel dengan kinerja sebesar 0,879. Hal ini terjadi hubungan sangat erat karena nilai mendekati 1 .

b. R Square $\left(\mathrm{R}^{2}\right)$ atau kuadrat dari $\mathrm{R}$, yaitu menunjukan nilai koefisien determinasi. Angka ini akan diubah kebentuk presentase symbangan pengaruh variabel independent terhadap variabel dependenr. Nilai $\mathrm{R}^{2}$ sebesar 0,773 artinya presentase variabel motivasi dan disiplin kerja terhadap kinerja sebesar 77,3\%, sedangkan sisanya dipengaruhi oleh variabel lain yang tidak dimasukkan dalam model ini.

c. Adjusted $R$ Square adalah $\mathrm{R}$ Square yang telah disesuaikan, nilai sebesar 0,753 menunjukan pengaruh variabel independent terhadap variabel dependent. d. Standar Error of Estimated (standar deviasi) adalah ukuran kesalahan prediksi, nilai sebesar 1,346 artinya kesalahan dalam memprediksi kinerja sebesar 1,346 .

\subsubsection{Analisis Regresi Berganda}

Data yang diperoleh dari responden dalam penelitian ini dianalisis dengan model regresi linier berganda dengan tujuan untuk mengetahui besarnya kontribusi dari variabel - variabel bebas (independent) dalam penelitian ini, yaitu variabel motivasi $\left(\mathrm{X}_{1}\right)$ dan variabel disiplin kerja $\left(\mathrm{X}_{2}\right)$ untuk memprediksi variabel kinerja (Y) sebagai variabel terikat (dependent), hingga dapat dijelaskan pula mengenai variabel bebas yang paling berpengaruh terhadap variabel terikatnya. Pengolahan data dilakukan dengan menggunakan program SPSS 23,0 dengan hasil pada tabel berikut.

Tabel 4.26.

\section{Hasil Uji Regresi Berganda}

Coefficients $^{\mathrm{a}}$

\begin{tabular}{|c|c|c|c|c|c|}
\hline \multirow{2}{*}{ Model } & \multicolumn{2}{|c|}{$\begin{array}{c}\text { Standar } \\
\text { dized } \\
\text { Unstandardized } \\
\text { Coefficients }\end{array}$} & $\begin{array}{c}\text { Cofficie } \\
\text { nts }\end{array}$ \\
\cline { 2 - 3 } & B & $\begin{array}{c}\text { Std. } \\
\text { Error }\end{array}$ & Beta & t & Sig. \\
\hline
\end{tabular}




\begin{tabular}{|cc|c|c|c|c|c|}
\hline 1 & (Constant) & 6.782 & 1.414 & & 4.796 & .000 \\
& MOTIVASI & -.292 & .243 & -.485 & -1.202 & .242 \\
& DISIPLIN & .863 & .260 & 1.340 & 3.323 & .003 \\
\hline
\end{tabular}

a. Dependent Variable: KINERJA

Dapat dijelaskan sebagai berikut: kolom $\mathrm{B}$ menunjukan nilainilai koefisien regresi untuk konstanta dan masing-masing variabel bebas $\left(\mathrm{X}_{1} \mathrm{X}_{2}\right)$, kolom (std. Error) menunjukkan nilai kesalahan baku untuk parameter koefisien regresi, kolom (Beta) menunjukkan besarnya koefisien regresi yang dlakukan atau menunjukkan koefisien jalur, kolom menunjukkan nilai t-hitung untuk masing-masing parameter koefisien regresi, dan koom (sig) menunjukan besarnya peluang kesalahan yang terjadi.

Berdasarkan pada hasil analisis yang telah dilakukan, maka persamaan regresi yang terbentuk adalah sebagai berikut:

$$
\begin{aligned}
& Y=a+b_{1} X_{1}+b_{2} X_{2} \\
& Y=6.782+-.292 X_{1}+.863 X_{2}
\end{aligned}
$$

Dari persamaan diatas dapat dijelaskan sebagai berikut :

a. Konstanta $(\alpha)$ sebesar 6.782 menyatakan bahwa jika variabel independen dikatakan konstan atau $=0$, maka Kinerja guru hanya sebesar 6.782 b. Koefisien regresi Motivasi $\left(b_{1}\right)$ sebesar -.292 hasil tersebut dapat diartikan bahwa setiap penurunan motivasi sebesar $1 \%$ maka akan mengakibatkan penurunanKinerja guru sebesar .292

c. Koefisien regresi Disiplin kerja $\left(b_{2}\right)$ sebesar .863hasil tersebut dapat diartikan bahwa ada peningkatan disiplin kerja 1\% maka akan mengakibatkan peningkatan Kinerja guru sebesar .863 .

\subsubsection{Uji-T (Secara Parsial)}

Uji $t$ atau uji koefisien regresi secara parsial digunakan untuk mengetahui apakah secara parsial variabel independent berpengaruh secara signifikan atau tidak terhadap variabel dependent. Dalam hal ini mengethaui apakah secara parsial variabel motivasi dan disiplin kerja berpengaruh secara signifikan atau tidak terhadap kinerja. Pengujian menggunakan tingkat signifikansi 0,05 .

Tabel 4.27.

Hasil Uji-T (Secara Parsial)

\begin{tabular}{|c|c|c|c|c|c|}
\hline \multirow[b]{2}{*}{ Model } & \multicolumn{2}{|c|}{$\begin{array}{c}\text { Unstandardized } \\
\text { Coefficients }\end{array}$} & \multirow{2}{*}{\begin{tabular}{|c|}
$\begin{array}{c}\text { Standardized } \\
\text { Coefficients }\end{array}$ \\
Beta \\
\end{tabular}} & \multirow[b]{2}{*}{$\mathbf{t}$} & \multirow[b]{2}{*}{ Sig. } \\
\hline & B & $\begin{array}{l}\text { Std. } \\
\text { Error }\end{array}$ & & & \\
\hline $1 \quad$ (Constant) & 6.782 & 1.414 & & 4.796 & .000 \\
\hline
\end{tabular}

Coefficients $^{\mathrm{a}}$ 


\begin{tabular}{|l|r|r|r|r|r|}
\hline MOTIVASI & -.292 & .243 & -.485 & -1.202 & .242 \\
DISIPLIN & .863 & .260 & 1.340 & 3.323 & .003 \\
\hline
\end{tabular}

a. Dependent Variable: KINERJA

Sumber : Hasil Pengolahan data dengan SPSS. 23.00

a. $\mathrm{H}_{0}: \mathrm{b}_{1}=\mathrm{b}_{2}=0$, artinya motivasi,disiplin kerjasecara parsial tidak mempunyai pengaruh terhadap Kinerja guru.

b. $\mathrm{H}_{1}: \mathrm{b}_{1} \neq \mathrm{b}_{2} \neq 0$, artinya motivasi, disiplin kerja secara parsial mempunyai pengaruh terhadap Kinerja guru

c. Pengujian dilakukan dengan uji $\mathrm{t}$ adalah memperhatikan derajat signifikan $95 \% \quad(a=0,05)$, apabila hasil pembuktian menunjukan :

t $\operatorname{sig} \geq \alpha$, maka $\mathrm{H}_{0}$ ditolak dan $\mathrm{H}_{\mathrm{a}}$ diterima

t sig $<\alpha$, maka $\mathrm{H}_{0}$ diterima dan $\mathrm{H}_{\mathrm{a}}$ ditolak

Hasil analisis uji $\mathrm{t}$ adalah sebagai berikut :

a. Nilai $t_{\text {hitung }}$ pada variabel Motivasi $\left(\mathrm{X}_{1}\right)$ adalah sebesar 1.202dengan tingkat signifikan sebesar $\quad 0,242 \quad$ Karena signifikansinya $0,242 \geq(\alpha) 0,05$ maka $\mathrm{H}_{0}$ ditolak dan $\mathrm{H}_{\mathrm{a}}$ diterima.
Kesimpulan : $X_{1}$ (Motivasi) tidak berpengaruh signifikan terhadap $Y$ (Kinerja guru).

b. Nilai $t_{\text {hitung }}$ padavariabel Disiplin Kerja $\left(\mathrm{X}_{2}\right)$ adalah sebesar 3.323 dengan tingkat signifikansi sebesar $\quad 0,03 \quad$ Karena signifikansinya $\quad 0,03<(\alpha) \quad 0,05$ maka $\mathrm{H}_{0}$ diterima dan $\mathrm{H}_{\mathrm{a}}$ ditolak. Kesimpulan : $X_{2}$ (Disiplin Kerja) berpengaruh signifikan terhadap $Y$ (Kinerja guru).

\subsubsection{Uji F (Uji Simultan/ Serempak)}

Uji-F atau uji Koefisien regresi secara bersama-sama digunakan untuk mengetahui apakah secara bersama-sama variabel independen berpengaruh signifikan terhadap variabel dependen. Dalam hal ini untuk mengetahui apakah variabel motivasi dan disiplin kerja berpengaruh secara signifikan atau tidak terhadap kinerja.

Tabel 4.28.

Hasil Uji- F (Uji Secara Simultan)

\begin{tabular}{|c|c|c|c|c|c|}
\hline \multicolumn{6}{|c|}{ ANOVA $^{\mathrm{b}}$} \\
\hline Model & Sum of Squares & Df & \begin{tabular}{|l} 
Mean \\
Square
\end{tabular} & $\mathbf{F}$ & Sig. \\
\hline $\begin{array}{ll}1 & \text { Regressi } \\
\text { on }\end{array}$ & 135.975 & 2 & 67.987 & 37.520 & $.000^{\mathrm{a}}$ \\
\hline Residual & 39.865 & 22 & 1.812 & & \\
\hline Total & 175.840 & 24 & & & \\
\hline
\end{tabular}

a. Predictors: (Constant), DISIPLIN, MOTIVASI 
b. Dependent Variable: KINERJA

Sumber : Hasil Pengolahan Data Menggunakan SPSS. 23.00

Berdasarkan uji ANOVA atau $\mathrm{F}$ test yang dapat dilihat pada tabel 4.28 Maka dapat diperoleh $\mathrm{F}_{\text {hitungsebesar } 37.520 \text { dengan tingkat }}$ signifikansi 0,000 .Oleh karena nilai Signifikan jauh lebih kecil daripada (a) 0,05 maka dapat dinyatakan bahwa variabel independen yang meliputi Motivasi $\left(\mathrm{X}_{1}\right)$, Disiplin Kerja $\left(\mathrm{X}_{2}\right)$ secara simultan atau bersama-sama Mempengaruhi variabel Kinerja guru (Y) secara signifikan.

\section{KESIMPULAN DAN SARAN}

\subsection{Kesimpulan}

Berdasarkan hasil analisis dan pembahasan dalam penelitian ini, maka dapat disimpulkan bahwa:

1. Dari hasil uji $F$ menunjukkan bahwa nilai $F_{\text {hitung }} 37,520$ atau $\mathrm{F}_{\text {hitung mempunyai tingkat sig }}$ sebesar $0,000 \leq 0,05$, sehingga hasil penelitian membuktikan Motivasi dan Disiplin Kerja secara bersama-sama mempunyai pengaruh yang signifikan terhadap Kinerja Guru SD Negeri 21 Palembang.

2. Hasil penelitian membuktikan bahwa:
a. Hasil uji t pada variabel motivasi menunjukkan bahwa nilai $t_{\text {hitung }}$
$(-1,202) \geq t_{\text {tabel }}(0,380)$ atau nilai sig $\geq \alpha(0,242 \geq 0.05)=$ $\mathrm{H}_{0}$ ditolak, artinya secara parsial atau individuvariable motivasitidak berpengaruh secara signifikan terhadap kinerja guru SD Negeri 21 Palembang.

b. Hasil uji t variabel disiplin kerja menunjukkan nilai nilai $\mathrm{t}_{\text {hitung }}(3,323)<\mathrm{t}_{\text {tabel }}(0,380)$ atau nilai sig $<\alpha(0,03<0,05)=\mathrm{H}_{0}$ diterima, artinya secara parsial atau individu variabel disiplin kerja berpengaruh secara signifikan terhadap kinerja guru SD Negeri 21 Palembang.

\subsection{Saran}

Berdasarkan kesimpulan di atas, dapat dikemukakan beberapa saran yang diharapkan dapat bermanfaat bagi perusahaan maupun bagi pihak-pihak lain. Adapun saran yang diberikan, antara lain:

1. Untuk pihak sekolah perlu memberikan kedisiplinan kerja yang membangun bagi para guru dan karyawan, memberikan peraturan yang tepat untuk meningkatkan disiplin kerja para guru dan karyawan, hal ini untuk meningkatkan kinerja para guru.

2. Diharapkan hasil penelitian ini dapat digunakan sebagai contoh bagi peneliti berikutnya untuk lebih mengembangkan penelitian ini dengan mempertimbangkan variabel-variabel lain yang merupakan variabel lain diluar variabel yang sudah ada dalam penelitian ini.

\section{DAFTAR PUSTAKA}

A.S Moenir. 2016. Manajemen Pelayanan Umum di Indonesia. Jakarta: PT. Bumi Aksara

Anwar Prabu Mangkunegara. 2015. Evaluasi Kinerja SDM. 
Bandung: PT. Remaja Rosdakarya

Anwar Prabu Mangkunegara. 2015.

Disiplin Kerja Perusahaan Cetakan Keenam, Bandung : Remaja Rosyada Karya

Barnawi dan Muhammad Arifin. 2016. Kinerja Guru Profesional. Yogyakarta: Arruzz

Hadari Nawawi. 2015.Penelitian Bidang Sosial. Yogyakarta : Gajah MadaPress

Hasibuan, Malayu. 2015. Organisasi dan Motivasi. Jakarta : PT. Bumi Aksara

Hasibuan, Malayu. 2015. Manajemen Sumber Daya Manusia Edisi Revisi Cetakan Keenam. Jakarta : PT. Bumi Aksara

Husein, Umar, 2015. Metode Penelitian untuk Skripsi \& Tesis. Jakarta: PT. Raja Grafindo Persada

Kartika Kurnia Idly, 2015. Pengaruh Motivasi dan Disiplin Kerja Terhadap Kinerja Pengajar Raudhatul Athfal(TK) Bunda Aminah Fikri Palembang. Skripsi : Universitas Palembang.

Lilistigfaroh Rohmalia, 2015. Analisis Pengaruh Motivasi dan Disiplin Kerja Terhadap Kepuasan Kerja Untuk Meningkatkan Kinerja Guru SMP,Mts dan MA Takhassus Al-Qur'an Demak. Skripsi : Universitas Sultan Fatah Demak

Martinis Yamin \& Maisah. 2015. Standarisasi Kinerja Guru. Jakarta : Gaung Persada Press

Mulyadi S, 2017. Ekonomi Sumber Daya Manusia. Jakarta : Rajawali Pers
Robert L. Marthis, John H. Jakson, 2015. Pengaruh Kinerja.

Diambil pada dari http://respository.usu.ac.id/blts ream/12345678/25947/4/chapt er.pdf.

Sugiyono. 2015 .Metode Penelitian Administrasi. Bandung : Alphabet

Sugiyono. 2016. Metode Penelitian (Kuantitatif,Kualitatif dan $R \&$ D). Bandung : Alphabet 